\title{
GHENTIN YLIOPISTON TORNIKIRJASTO
}

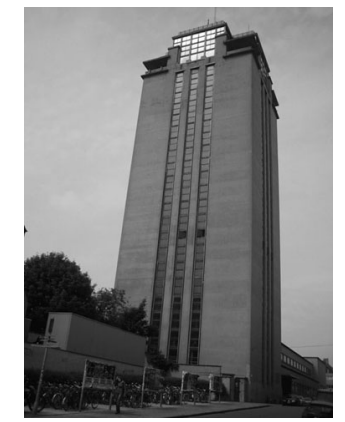

Valokuva: Kimmo Sarje, 2008.

"Ja en ole unohtanut monia keskusteluja yhteisen työpöydän ääressä ja kävelyillämme Weimarin linnanpuistossa ja Belvederen puistossa", arkkitehti Henry van de Velde (1863-1957) muistelee lämmöllä yhteistyötään nuoren suomalaisen kollegansa Sigurd Frosteruksen (18761956) kanssa 1900-luvun alun Weimarissa. Työskentely van de Velden toimistossa vahvisti Frosteruksen taiteellista ja älyllistä kutsumusta, ja hän tunsi osuneensa oikeaan aikaan oikeaan paikkaan. "Te olette minulle enemmän kuin kaikki muut ihmiset ovat olleet", Frosterus tunnustaa kirjeessään 25.4.1905 belgialaiselle ystävälleen ja kollegalleen.

Arkkitehtien keskinäinen arvostus oli jaettua, ja van de Velde ehdottikin Frosterukselle yhteisen toimiston avaamista molempien nimillä. Frosteruksesta tarjous oli "melkein huimaava tulevaisuudenperspektiivi". Perusteellisen harkinnan jälkeen hän päätyi itsenäisen uran kannalle. Palattuaan Suomeen hän teki tunnetuksi sekä teoreettisesti että käytännöllisesti van de Velden arkkitehtuurin ja muotoilun lähtökohtia. Monissa Frosteruksen suunnittelemissa huonekaluissa, sisustuksissa ja parissa asuinkerrostalossakin oli belgialaiselta mestarilta omaksuttuja piirteitä: dynaamisia kaartuvia muotoja ja abstrakteja ornamentteja rationaalisen art nouveaun hengessä. Myös arkkitehtien kirjeenvaihto jatkui.

Ensimmäinen maailmansota järkyttävine tapahtumineen pakotti sekä van de Velden että Frosteruksen arvioimaan uudelleen taiteensa ja maailmankatsomuksensa lähtökohtia. He ajautuivat omille tahoilleen ja yhteydenpitokin lakkasi. Frosterus sanoutui irti van de Velden ekspressiivisestä, aaltoilevia muotoja korostaneesta tyyli-ihanteesta ja sen sijaan painotti rakenteellisuutta, arkkitehtuurin perinteitä ja käsityötaitoa talorakentamisessa. Mutta myös van de Velden arkkitehtuuri muuttui pidättyväisemmäksi.

Van de Velden myöhäistuotannon yksi pääkohde on Belgian Ghentissä sijaitseva yliopiston kirjastorakennus, jonka tunnusmerkki on kirjavarastona toimiva monumentaalinen torni. Kyse on sivistyksen symbolista kaupunkisiluetissa, jolle mahtavat keskiaikaiset katedraalit ja kellotorni antavat leimansa. Kirjatornin näkyvyyttä lisää, että se on pystytetty kukkulalle. Alun perin van de Velden projekti käsitti kokonaisen yliopistokampuksen, mutta hänen piirustustensa mukaan toteutettiin vain kirjasto. Monien epäonnekkaiden käänteiden tähden vuonna 1936 alkaneet rakennustyöt saatiin päätöksen vasta vuonna 1943. Kirjaston pelkistetyssä interiöörissä on hienostuneita yksityiskohtia, ja monet huonekalut ovat van de Velden suunnittelemia. Lukusalia jalostavat ruutuihin jaettu lasikatto ja näkymä suurista ikkunoista sisäpihalle. Ankarat vertikaaliset ja horisontaaliset ikkunanauhat strukturoivat rakennuksen harmaita, rapattuja julkisivuja.

Samana vuonna 1936 kun van de Velden kirjastoa alettiin rakentaa, Sigurd Frosteruksen ja Ole Gripenbergin suunnittelema Pohjoismaiden Yhdyspankin punagraniittinen päärakennus valmistui Helsingin Aleksanterinkadulle. Huolimatta pankin klassisistisista viitteistä samantapainen kurinalaisuus ja tarkoituksenmukaisuus yhdistävät rakennuksia. Erityisesti sen voi aistia lasikattojen valaisemien pankkisalin ja lukusalin hillityssä art deco-muotoilussa. Ehkä Weimarin Belvederen puistokävelyjen vuoropuhelu ei katkennutkaan? Onhan kirjatorninkin huipulla avara Belvedere-sali upeine kaupunkinäkymineen. 